\title{
Towards Data Integration and Analysis in the Detection of Terrain Surface Deformation in the Case of the Inowrocław Salt Dome***
}

\section{Introduction}

Due to the rapid development of geodetic measurement techniques, including satellite-based ones, new research problems have emerged. They often arose at the interface of different specialisations in the field of geodesy, but also other disciplines of geosciences, such as geology, geophysics etc. In many cases, different measurement techniques need to be combined. An example of this is the description of large area terrain surface deformation. Given the costs of levelling measurements, the use of the InSAR technique for terrain surface observations can then seem useful, depending on the objectives of such research. Although the levelling method can produce high-accuracy results, the information gained from measurements is limited to stable reference points and the costs of such research can be substantial. In turn, a drawback of measurements using the InSAR technique relates to the reliable estimation of the accuracy of the displacements determined. However, the analysis results can cover a substantial number of points dispersed on a large surface. The linking of InSAR and levelling measurements seem to be a certain way of combining the advantages of both methods and minimising their disadvantages.

The approach presented in the study, involving the linking of the results of InSAR measurements with those of levelling measurements, poses certain opportunities for interpretation: the determination of the vertical displacements between levelling measurement campaigns and the determination of the vertical displacements of areas or spots uncovered by levelling. The present analysis concerns displacements

* AGH University of Science and Technology, Faculty of Mining Surveying and Environmental Engineering, Department of Mining Areas Protection, Geoinformatics and Mining Surveying, Krakow, Poland

** The Polish Geological Institute, Warsaw, Poland

*** This study (geodetic part) was carried out in the framework of AGH University of Science and Technology research project No. 11.11.150.195 and in the framework of PIG PIB Project no. 61.9202.1101.00.0: Application of SAR interferometric methods to identify the mobility of the area above salt diapir in Inowrocław town 
in the area of the salt diapir in Inowrocław. It is one of the numerous diapirs of the Zechstein salt-bearing formation, which are popular tectonic structures in the Polish Lowland (Fig. 1). In recent years, salt deposits played an increasingly important role, not only in terms of mining. This results from the physical and mechanical features of deposit formations which are used e.g. as hydrocarbon storage sites.

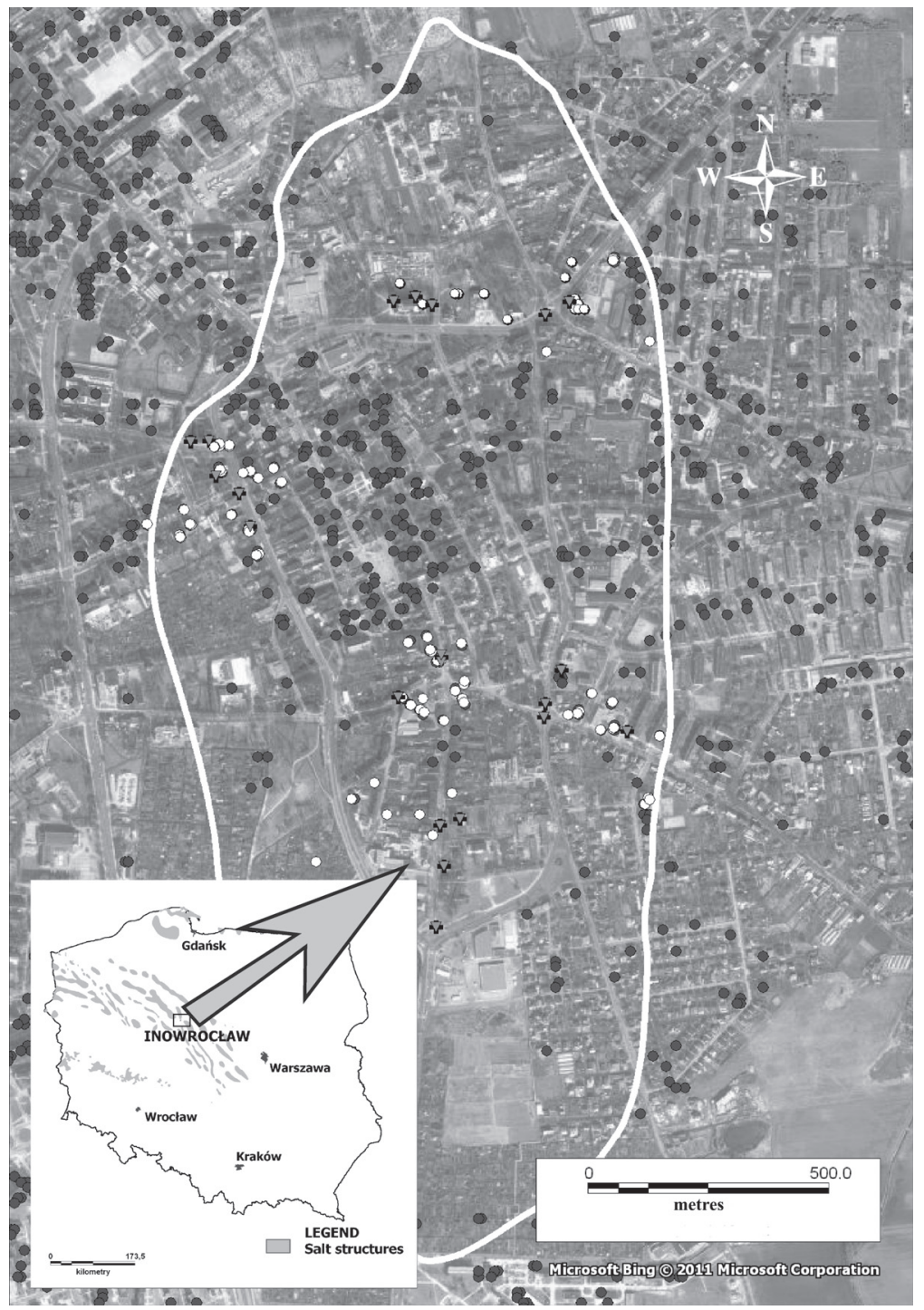

Fig. 1. The localization of area of the study on the National Map and Local Map: black point Persistent Scatterer Interferometry (PSI) - all series point of interferometry processing; white point - PS point near the geodetic measurement point; inverted triangle point - geodetic measurement point (Microsoft Bing Maps) 


\section{Environmental Background}

The measurements using the Interferometric Synthetic Aperture Radar, InSAR, and precise spirit levelling methods as discussed below were carried out in the area of Inowrocław (Figs 2, 3). The work implemented in the geodynamic network set up in 2002 in the area of the salt diapir in Inowrocław encompassed research in the field of geodesy and geophysics.

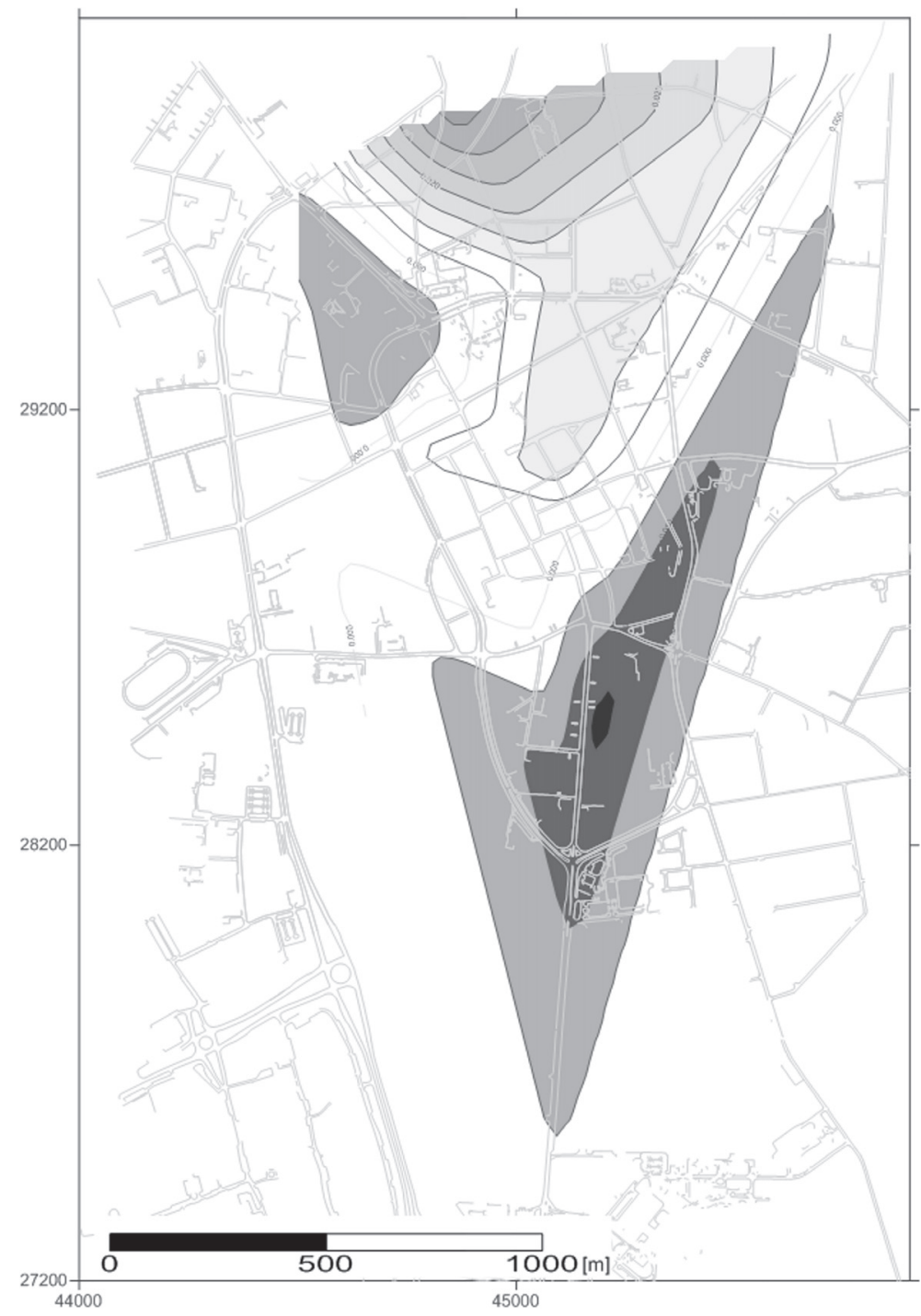

Fig. 2. The distribution of vertical displacements on the area of Inowrocław between 1992 and 2007 
The present study is a continuation of the earlier articles published in this periodical, which concerned e.g. terrain surface deformations determined using the GPS technique and the precise spirit levelling method [28, 29] and the linkage between the abovementioned deformations with the morphology of the terrain surface [31]. More information concerning the status of geodetic and geophysical research in the area of Inowrocław and the geological and mining conditions of the deformations observed can be found in the study by Szczerbowski [30]. In the course of several years long geodetic observations, regularities can be found in the surface deformation process in the city. The deformation distribution indicates a combination of the different causes of uplifts and cases of subsidence (Fig. 2).

They include an important diapiric movement of the salt structure - the most probable cause of the uplifts which have already been registered for many years in the northern part of the city. In turn, the cases of subsidence in the southern part of the diapir can be related to underground erosion and the still persisting impacts of the old, shallow extraction of the deposit. The geological and mining conditions in this area were already discussed earlier [23, 28, 29, 31], and in this study the authors only considered the general characteristics of the area.

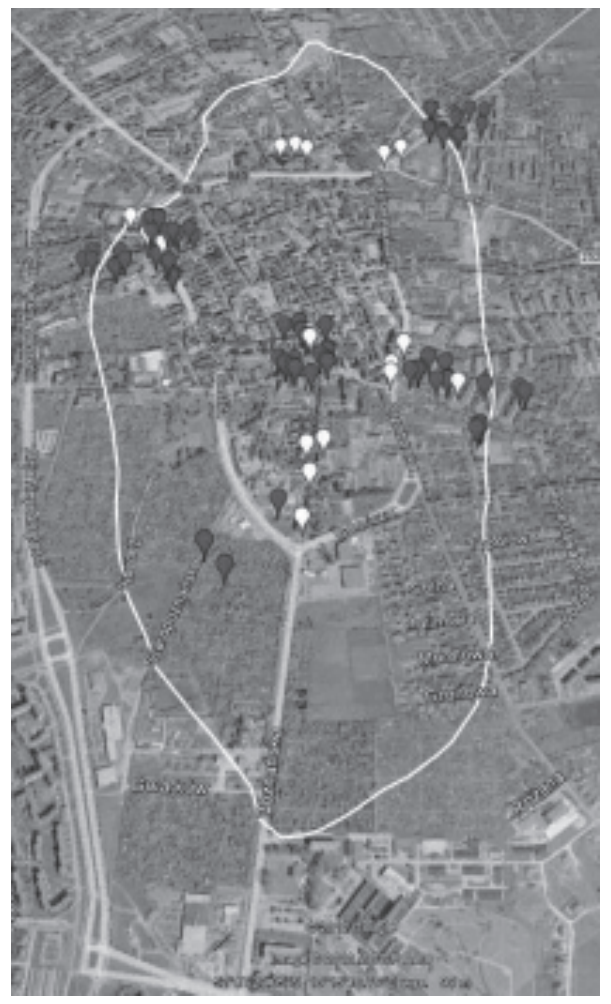

Fig. 3. The map of localization of analyzed PS points and levelling benchmarks 
Although in a horizontal projection the Inowrocław salt diapir has a relatively small surface area and resembles an ellipse with the longer, approximately $3 \mathrm{kme}-$ tres long parallel-oriented axis and the shorter, approximately $1 \mathrm{~km}$ long axis, the large vertical range of its occurrence results in effect in a huge volume of the accumulated mass of the deposit formations (Fig. 3).

The kinematic mechanism of Inowrocław salt structures is clearly translated into the regional salt structures. The salt formation and the respective locations on the land surface corresponding to the pre-Quaternary surface uplifts show a tendency of uplifting [21]. An additional element which probably influences land movement (displacement) is salt minig. Those mining operations certainly influenced the rock mass stress-relieving nature, within the studied structure, augmenting the elevation effect [20].

When analysing the occurrence of salt structures, we should mention the compensation troughs, associated with the "outflow" of salt masses from the surroundings of the salt body being elevated to its centre. That phenomenon is also reflected in the land surface movement [1]. Ground subsidence, documented by Persistent Scatterer points, indicates exceptional matching with the compensation troughs situated in the direct vicinity of the salt diapirs [22].

\section{Survey Data}

Levelling and satellite-based measurements, the results of which are analysed in the present paper, were carried out for different purposes. Initially, the aim of geodetic measurements was to assess the stability of the terrain surface in relation to the closure of the Solno Mine and to evaluate the threats posed to build structures by the salt solution effects, including the geodetic monitoring of a church in Inowrocław which was damaged by these processes. Later, the geodetic works were extended with GPS observations and were carried out in the context of the geodynamic monitoring of the diapir area. Interferometric Synthetic Aperture Radar measurements (by the PSI method) were analysed in order to assess terrain surface movements as a halotectonic effect at the level of the diapir as a whole. However, the results presented below concern only selected areas of the deposit. The present analysis is limited to selected levelling points and PSI (Fig. 3). The vertical displacements of these points should be treated as representative of the individual parts of the terrain surface in Inowrocław.

\subsection{Levelling Surveys}

Precise levelling surveys were carried in the area of Inowrocław simultaneously with GPS surveys. The aim of the surveys was to determine ground displacements as an element of the monitoring of salt dome kinematics or the influence of old mining. Gravimetric, seismic and ground penetrating radar GPR investigations were carried out as well. 
The displacement of the terrain surface was an effect of several factors:

- natural halotectonic uplift,

- subrosion (a natural degradation of a soluble rock),

- mining (subsidence caused by old mining and the Solno, a mine closed down in 1991).

The ground benchmarks established in 2002 formed a geodynamic network and they supplemented the previously existing wall benchmarks which were possible only for levelling observations (an old mine network with more than 100 points). The ground control points were located around the salt deposit. The levelling observations carried out in 2002, 2004, 2005, 2006 and 2007 were highly accurate (the standard error of the determined height of a single point usually amounted to $\pm 1 \mathrm{~mm}$ ). Figure 2 shows the displacements of the terrain surface in the period of 1992-2007. It is a representative outline of deformations occurring in the city area. Certain regularities in the distributions of deformations were observed during successive levelling campaigns. Considering the period of two decades, it can be stated that there is a trend of deformations: the northern part of the city area is uplifted due to the halotectonic process, the southern area subsides as a result of shallow old mining (exploitation by drillings or in shallow - 100-150 m below surface - mining workings). Some aspects of the problem were discussed by Szczerbowski (2007). The difficulties of levelling measurements were related to a loss of benchmarks, a shortage of control points and the costs of surveys. Therefore, InSAR surveys were carried out and the results presented further on were analysed with a view to determining the usability of the method.

\subsection{PSI Investigations}

In the detection of land surface deformation on salt dome Inowrocław was used the Persistent Scatterer Interferometry (PSI) method. This method consists in the identification of the PS points on the research area, i.e. the permanent persistent scatterers. It consists in the comparison of the scenes for the same terrain, the same orbit and the same satellite. Such a set should consist of at least 20 scenes (with the 35-day re-emission time for the ERS satellite), which represent a dataset covering a period of several years. Interferogram sets arise, where PS points are identified on the basis of coherence [8] or amplitude [4]. Only those points that are characterised by stable wave scatterings are qualified for further analyses; in practice, these are building roofs, poles, salt outcrops and elements of aboveground [15-19]. As a result of data processing, a value of displacement velocity in the direction of the satellite imagery (Line of Sight) in millimetres per year is assigned to each point. This is a relative value, measured for one or two benchmarks which are considered to be stable $[5,6,10,11,19,25,26]$. The particular points are assigned the values of relative displacements from each scene (a set of values) with reference to one benchmark scene. This gives rise to plots representing the displacement cycle in time, i.e. the so-called time series. This method allows for the identification of small-displacements for example, for landslides [13, 14]. 
The mobility of the surface area of the salt dome in Inowrocław consists of many natural factors (halotectonic) and induced (post-mining caverns filled brine). Determination of the origin of this movement is complicated. Nevertheless, an attempt has been made to decipher the mobility of the salt dome phenomenon of geodetic and interferometric methods. They have some advantages that are discussed further on. The interferometric observations of the ground mobility in Inowrocław, conducted on the basis of the ERS 1/2 SAR, covered the period of 1993-01-17-1998-08-10. The analysis was conducted on the local scale (the Inowrocław diapir). We can infer from the presented interferometric data on the PS point (Persistent Scatterer) value distribution in respect of the Inowrocław salt diapir that it is elevating in some parts.

For comparative studies were used PS points, developed in the framework of the project: Morphotectonic Map of the European Lowland Area (MELA). This Project was prepared within the Human Resources and Mobility (HRM) Activity, Marie Curie Actions, Marie Curie Host Fellowships for the Transfer of Knowledge. The analysis was carried out by experts from the CNR-ISSI in Bari (Italy). PS results were performed by Fabio Bovenga from CNR-ISSI in Bari (Italy) and there was used SPINUA algorithm. The area of analysis was about $30 \times 25 \mathrm{~km}^{2}$ and had a dataset: ERS-1/2 from 1993 to 1998 . Where the master display was adopted 1997. Received from the contractor a set of PS points has a normal distribution, the values of velocity displacement from $+6 \mathrm{~mm} / \mathrm{yr}$ to $-6 \mathrm{~mm} / \mathrm{yr}$. More about the algorithm is described in [2].

\section{Comparative Analysis of the Survey Results}

The continuity of the levelling measurements carried out earlier by the mine services was broken due to the closure of the Solno Mine which had operated on the salt diapir. Further observations were continued by a team of the AGH University of Science and Technology in 2002-2009. Based on at long-term levelling measurements it was possible to determine the characteristics of the terrain surface deformation process. In the 1990s, the subsidence was halted over an overwhelming part of the area slight uplifts, i.e. those with values close to the uplift measurement error, were found. The time gap arising in the levelling measurements prevents the precise determination of the date when significant positive changes appeared and a long-term trend was reversed. The results of the measurements carried out after 2002 confirmed the occurrence of uplifts in the northern and central part of the diapir and made it possible to define the uplift rate as $1-2 \mathrm{~mm} / \mathrm{yr}$ (Figs 2, 4). The problem of the trend change date can be solved by analysing the measurement results using the PS InSAR ${ }^{\circledR}$ method.

Although both methods enable the determination of the vertical displacements of the terrain surface in a built-up area, their results are slightly different in nature. Levelling measurements are carried out at various intervals ranging between one year to even several years. The distributions of vertical displacements obtained on this basis are usually derived from a limited number of datum points. The loss of individual datum points causes the absence of information on displacements for 
a particular spot or area of investigation. In the case of the analysis of vertical terrain surface deformations in Inowrocław, satellite-based measurements have this advantage that they enable information to be gained from a larger number of points and for a larger number of measurement epochs. This, in turn, makes it possible to determine the vertical displacement distributions for those parts of the city where there are no datum points or for those time periods when levelling measurements were not carried out. In the case of PS InSAR ${ }^{\circledR}$ satellite-based measurements, a major problem is the lesser accuracy of the displacements determined, resulting e.g. from a large number of interfering factors. In a further part, the approach to the analysis and application of the results of PS InSAR ${ }^{\circledR}$ measurements is presented as regards the minimisation of the errors of this method, comparison with the results of levelling measurements and the substitution for them when field measurements are absent (time gaps in levelling measurements).

Certain regularities can be seen in the time distributions of the vertical displacements of the PS points. These regularities concern single distributions or distributions for adjacent points. All the distributions are characterised by some variability. In respect of the amplitude, the variability of the $1^{\text {st }}$ order can be distinguished, which can be related to natural seasonal changes caused by ground movements, and so can changes of the $2^{\text {nd }}$ order, which are caused by random interfering factors (related mainly to radar wave reflection). For a given year or for several years a trend can be identified, which determines the mean vertical displacement rate in a given area. The adjacent points are characterised by similar trend characteristics and first-order oscillations. When levelling measurements are carried out in annual and longer periods it is usually impossible to observe natural seasonal ground changes. The levelling measurements carried out in 2002-2009 in some areas of Inowrocław showed an oscillatory nature of vertical displacements with a distinct positive or negative trend. The determined values of the datum point oscillations which were caused by seasonal factors amounted as a maximum to about $5 \mathrm{~mm}$. This issue was considered in greater detail in a paper by Szczerbowski [29]. Oscillations with similar amplitudes show the displacements of PS InSAR ${ }^{\circledR}$ points. A comparative analysis of the displacements of these points and levelling datum points is presented for selected areas of the city. The designation of areas is justified by the different terrain surface deformation characteristics (subsidence, uplift) in the particular parts of the area analysed. The further division of the areas (e.g. of Area B into B1 and B2) follows from the further differentiation of displacements, e.g. their rates.

\section{Area A}

For a dozen years or so the terrain surface in the central, northern and north-eastern parts of the city demonstrated positive height changes. The data from satellite-based measurements concern exactly this part of the city which is denoted as Area A. The terrain surface deformation characteristics of this area are represented by the vertical displacement distribution of selected wall datum points 127, 112, 731 and 732 (Fig. 4). 
The vertical displacement oscillations to be seen in the figure relate to the period when the observation frequency was increased. The value of the displacement oscillation amplitude is close to the amplitude values of the PS InSAR ${ }^{\circledast}$ points located in the vicinity.

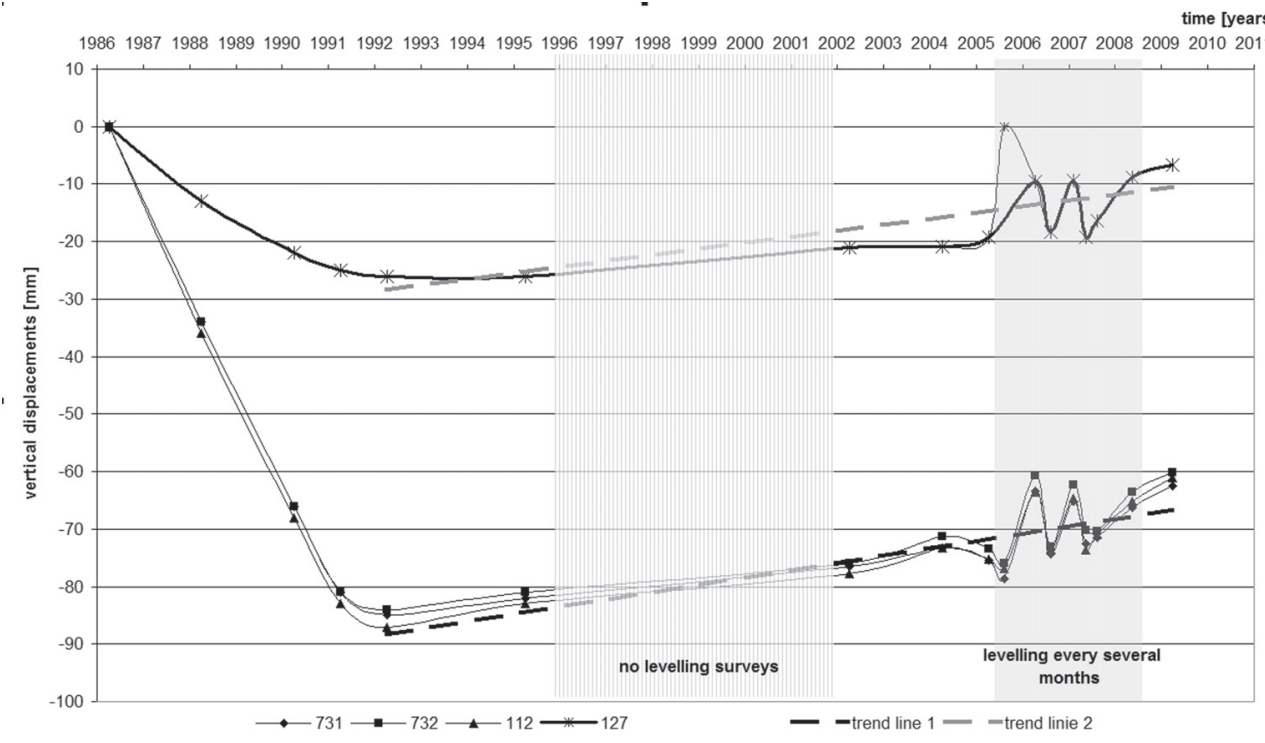

Fig. 4. Distribution of vertical displacements in the period 1986-2009 of some benchmarks located in the northern part of the deposit

time [years]

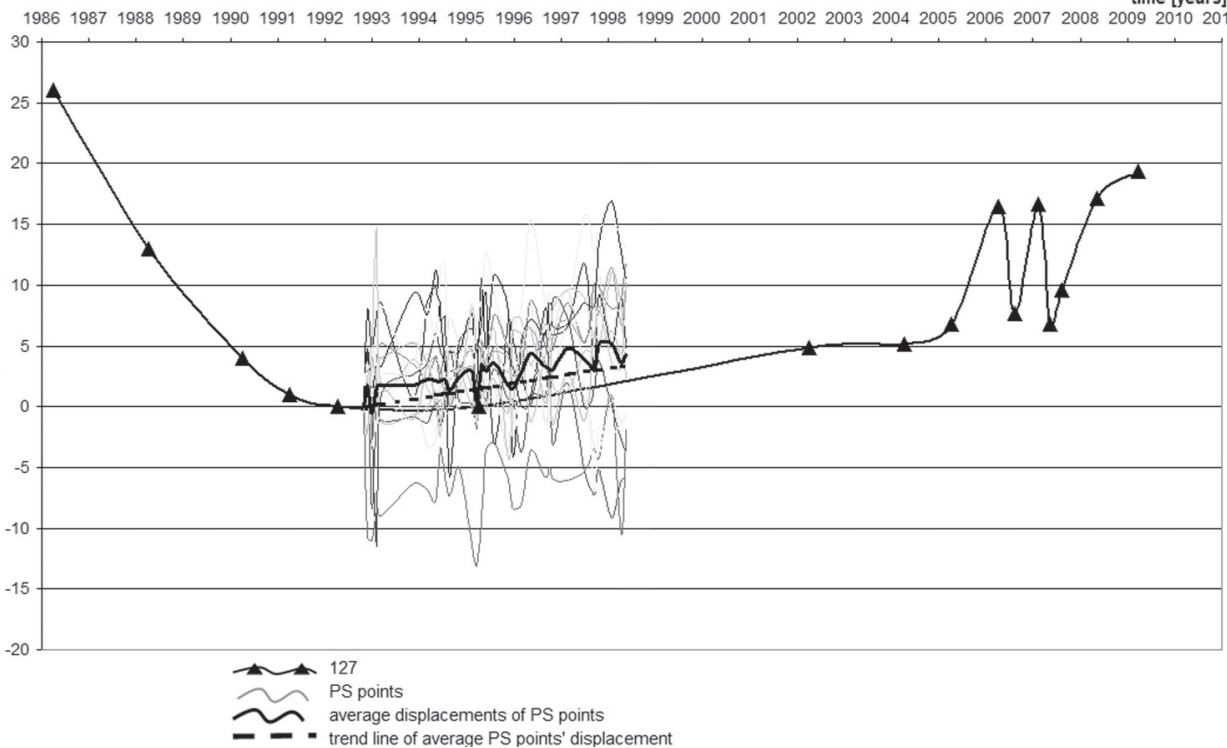

Fig. 5. Distributions of vertical displacements of the 127 benchmark and PS points in relation to 1992 
This problem is illustrated in a successive figure where the height changes of these points are compared with the vertical displacements of datum point 127 (Fig. 5).

These displacements were referred to 1992 - just before the first session of the satellite-based observations analysed (in 1993 there were no levelling measurement campaigns).

\section{Area B}

It is located close to the southern and eastern borders of the deposit. This is an area where the terrain surface subsides. Given the situation of the PS points in the different parts of the city with respect to the deposit borders, the southern area B1 and the eastern area B2 were designated. Just as in the preceding case, the vertical displacements were referred to 1992.

\section{Area B1}

In this area, despite the closure of the mine, subsidence is observed. Its characteristics are similar for all the points in this area (datum points GPS8, 132 etc.). The terrain surface subsidence process in this area of the city is illustrated with the presented distribution of height changes of datum point 132 (Fig. 6).

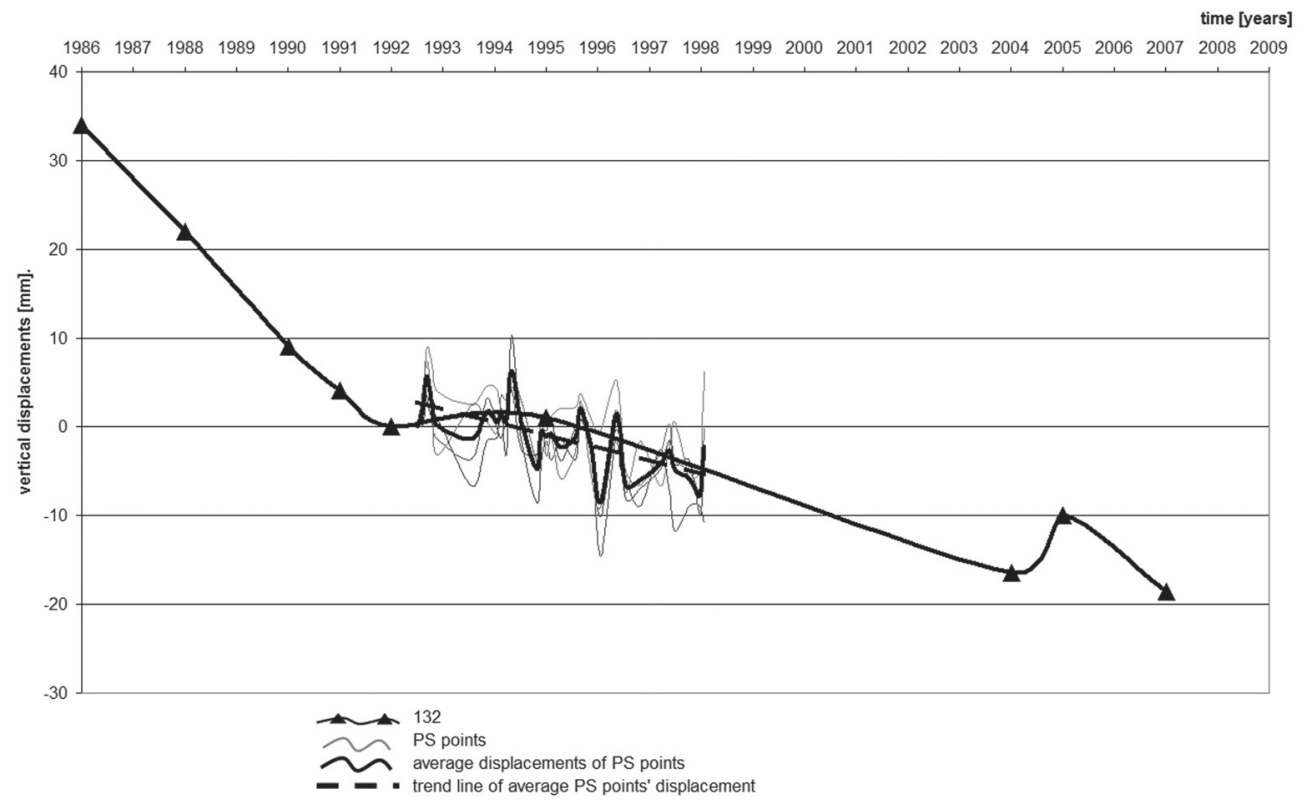

Fig. 6. Distributions of vertical displacements of PS points and the 132 benchmark in relation to 1992

The subsidence rate has been stable since the mine was closed down, amounting to about $1.5 \mathrm{~mm} / \mathrm{yr}$. The case is similar with PS points. The trend of their height changes is negative and the rate calculated on its basis is also $1.5 \mathrm{~mm} / \mathrm{yr}$. 


\section{Area B2}

The terrain surface displacements in the area of the geodetic point GPS7 and three old mine datum points $(128,193,194)$ were found to have similar characteristics to those in the case of Area B1 nearby (Fig. 7).

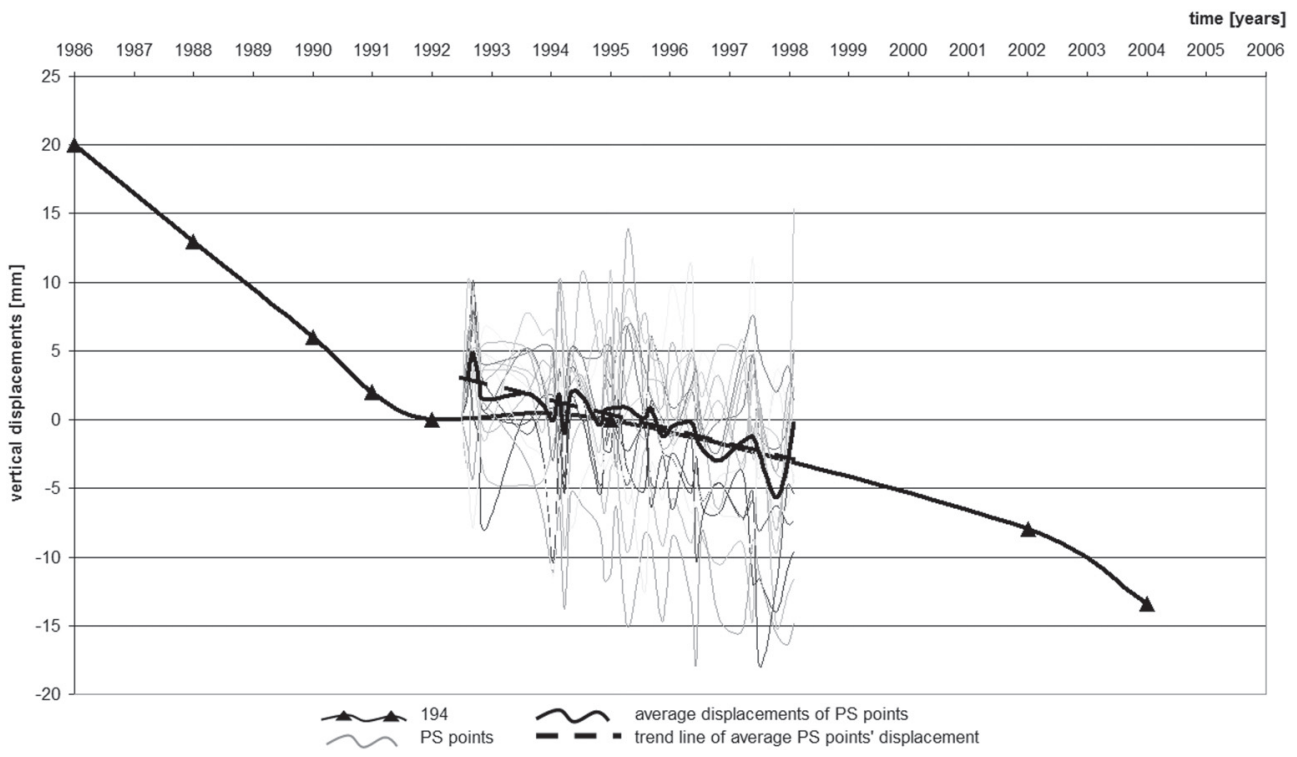

Fig. 7. Distributions of vertical displacements of PS points and 194 benchmark in relation to 1992. Other explanations in the text

Negative height changes of the datum points, with varied rates in individual years, are also observed. PS points demonstrate similar characteristics, with a distinct negative trend in height changes. The mean annual subsidence rate derived from the trend is about $1.5 \mathrm{~mm} / \mathrm{yr}$. This value is similar to the annual vertical displacements for the levelling points in this area. In turn, in the period of 1986-2005 the mean subsidence rate was about $2.5 \mathrm{~mm} / \mathrm{yr}$.

\section{Area C}

It is located roughly over the central part of the deposit area and close to its western border. The vertical terrain surface displacements are intermediate with respect to those described above; both uplifts and subsidence of datum points can be observed. Thus, this area borders on negative areas which distinctly demonstrate subsidence and uplifts. Given the situation of datum points and PS points, two areas were designated: the central $\mathrm{C} 1$ and the western $\mathrm{C} 2$.

\section{Area C1}

The geodetic datum point GPS6 and old mine datum points (52 and 541) are situated in the zone where the sign of vertical displacements changes. This zone extends roughly longitudinally over the central part of the diapir and demonstrates very 
small or no height changes. In general, it divides the city area situated over the diapir into the northern area which is subject to uplift and the southern area which subsides. The maximum relative velocities of positive and negative displacements are close. The distribution of height changes of the two datum points shown in the Figure 8 reflects the differentiation of the subsidence characteristics in this zone: in recent years one of the datum points subsided at a rate of $1 \mathrm{~mm} / \mathrm{yr}$, while the other demonstrated slight height changes (slight uplift and subsidence). The displacement characteristics of the PS points in this zone are similar, although at first sight they seem chaotic and random. However, the trend analysis shows results which are similar to those obtained from levelling. Thus, the diagram shows that some of the PS points demonstrate vertical displacements with a negative trend at a rate of about $1 \mathrm{~mm} / \mathrm{yr}$ as well (trend line 2). The displacement trend of the other points demonstrates practically no movement at all (line trend 1). Thus, in this case, too, the PS points in their group and levelling datum points demonstrate similar displacement characteristics.

time [years:

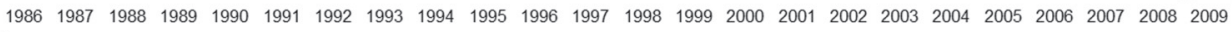

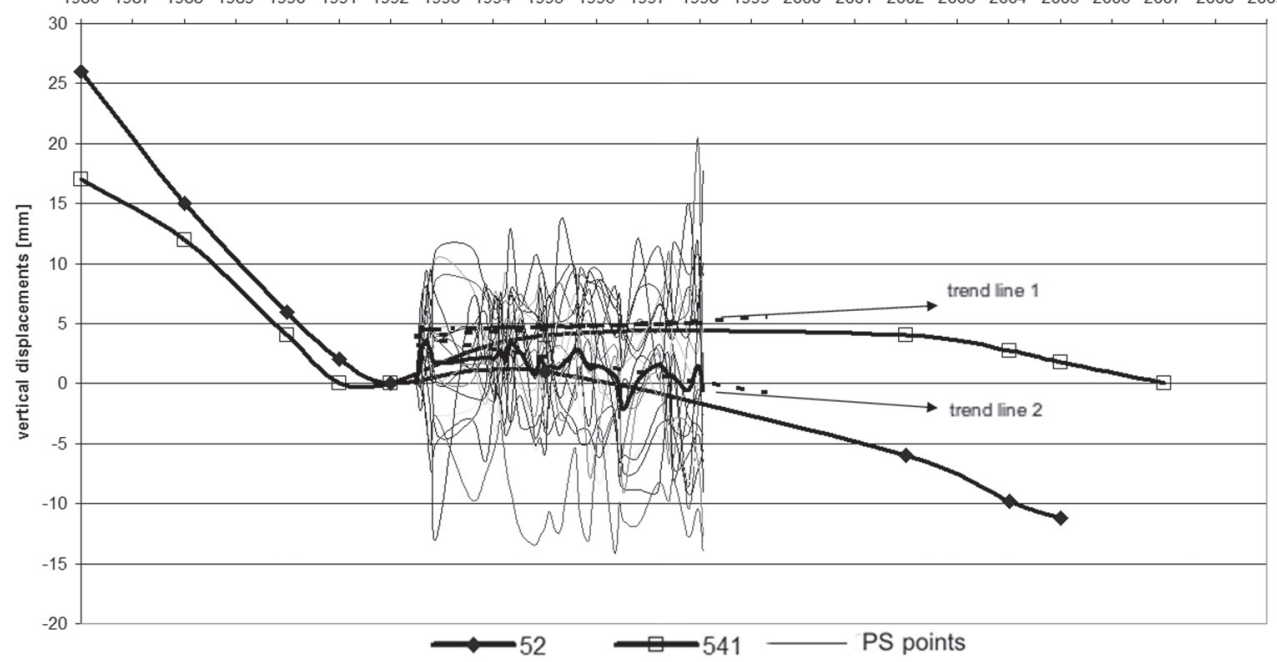

Fig. 8. Distributions of vertical displacement of PS points and the 52 and 541 benchmarks in relation to 1992. Other explanations in the text

\section{Area C2}

Just as in the case of Area C1, both positive and negative displacements of levelling points (datum points GPS17, 66, 67, 538 and 148) were observed in recent years, i.e. after the closure of the Solno Mine. The uplift rate was determined to be about $2 \mathrm{~mm} / \mathrm{yr}$ (Fig. 9). This value is quite significant with respect to the cases of subsidence identified to unfold at a rate of about $0.5 \mathrm{~mm} / \mathrm{yr}$ in this area. In this case, too, the annual vertical displacement rates of datum points and the height change rates of the PS points derived from the trend have been found to be similar. 


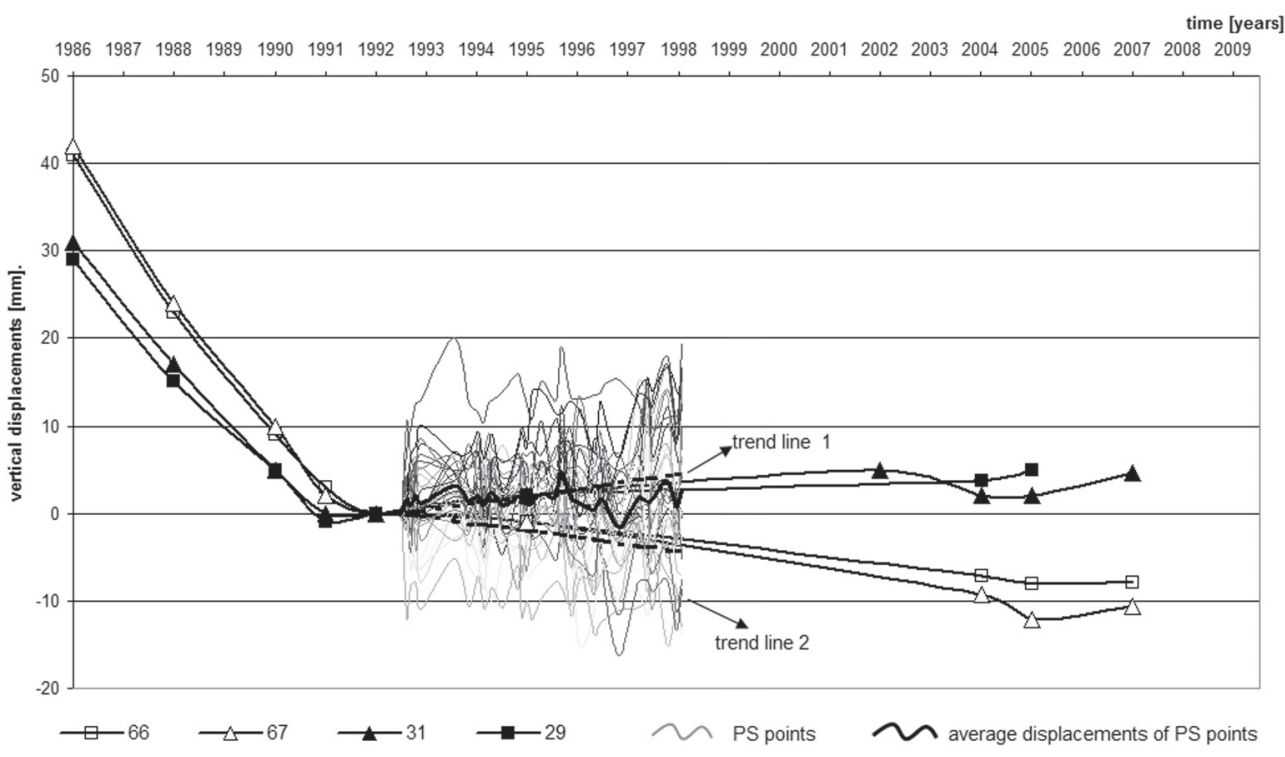

Fig. 9. Distributions of vertical displacement of PS points and 66, 67, 31, 29 benchmarks in relation to 1992. Other explanations in the text

\section{Conclusions}

The aim of the present paper was to compare the results obtained by levelling measurements and PS research. The PS research results show relations to displacements derived from levelling. However, the areas displaying a tendency to subside from $1-2 \mathrm{~mm} / \mathrm{yr}$ are probably associated with the gypsum-salt cap complex. The subsidence values ranging from $-4 \mathrm{~mm} / \mathrm{yr}$ to $-1 \mathrm{~mm} / \mathrm{yr}$ appear in the areas of the abandoned extraction shafts. The concentration of the PS points showing a tendency to subside occurs in the areas of the southern part of the deposit, which was confirmed by geodetic studies based on repeated precise levelling data [28].

A slow uplifting movement is also indicated by the PS points situated in the northern part of the deposit with the values from $0 \mathrm{~mm} / \mathrm{yr}$ to $+8 \mathrm{~mm} / \mathrm{yr}$. The slow diapir mass uplifting movement indicates a natural process of the phenomena subjected to the laws of halotectonics [7,27]. The intermediate area separating uplifts and subsidence was pointed out as well.

We should emphasize that there is a clear relationship between the vertical movement rates and the changeability of the lithological gypsum cap formation, including its thickness.

We also found a clear correlation between the morphology of the pre-Quaternary surface and the recent movements. The deformation velocities obtained from PS were compared with an isoline map of the Quarternary sediment base (with the compilation based on the geological data from $[3,9,12,24,32]$. 
When comparing the results of vertical displacements determined by levelling and interferometric methods, it should be borne in mind that in the case of the latter the measurement does not involve stable points. An effect of this is a large random scatter of the height changes of the points located in a given area which are determined using the PS technique.

The situation is similar in the case of the time distributions of height changes for the particular points - they are characterised by oscillations with an amplitude of several millimetres. However, these distributions demonstrate a distinct trend. A trend analysis produced results which were consistent with the displacements determined by levelling. At the same time, the abovementioned data gave information about the vertical terrain surface displacements in the period when no levelling measurements were carried out. The required further analysis covering all the PS points can specify in greater detail the time and space distribution of vertical displacements, which means the acquisition of information on the areas or time periods which have not been covered by the levelling measurements. The results of such an analysis can describe better the kinematics of the salt diapir and ensure a better understanding of the halotectonic processes.

\section{References}

[1] Baraniecka D.M.: Geneza elementów wklęsłych powierzchni podłoża czwartorzędu na obszarze wału kujawskiego i niecki warszawskiej. Biuletyn Instytutu Geologicznego, nr 322, t. 24, 1980, pp. 31-64.

[2] Bovenga F., Nutricato R., Refice A., Guerriero L., Chiaradia M.T.: SPINUA: a flexible processing chain for ERS/ENVISAT long term interferometry. Proceedings of ESA-ENVISAT Symposium, Salzburg, Austria, 6-10 September 2004.

[3] Brzeziński M.: Objaśnienia do Szczegółowej mapy geologicznej Polski 1:50 000. Arkusz Inowrocław. PIG-PIB, Warszawa 2009.

[4] Ferretti A., Prati C., Rocca F.: Permanent Scatterers in SAR Interferometry. IEEE Transactions on Geoscience and Remote Sensing, vol. 39 (1), 2001, pp. 8-20.

[5] Graniczny M. et. al (eds): Proceedings of the conference "Mass movement hazard in various environments": October 20-21, 2005, Kraków, Poland. Polish Geological Institute Special Papers 20, Polish Geological Institute, Warszawa 2005.

[6] Graniczny M., Bovenga F., Kowalski Z., Perski Z., Piątkowska A., Surała M., Uścinowicz S., Wasowski J., Zdanowski A.: Problematyka wykorzystania interferometrii satelitarnej w badaniach geologicznych. Biuletyn Państwowego Instytutu Geologicznego, t. 446, nr 446/1, 2011, pp. 53-64.

[7] Hardy H.R. Jr., Langer M. (eds): The Mechanical behavior of salt: proceedings of the first conference held at the Pennsylvania State University, University Park, Pennsylvania, November 9-11, 1981. Gulf, 1984. 
[8] Hooper A.: A multi-temporal InSAR method incorporating both persistent scatterer and small baseline approaches. Geophysical Research Letters, vol. 35, issue 16, 2008, DOI: 10.1029/2008GL034654.

[9] Jeziorski J.: Objaśnienia do Szczegółowej mapy geologicznej Polski 1:50 000. Arkusz Gniewkowo. Państwowy Instytut Geologiczny, Warszawa 1995.

[10] Krawczyk A., Perski Z., Hanssen R.: Application of ASAR interferometry for motorway deformation monitoring. ESA ENVISAT Symposium, Montreux, Switzerland, 23-27 April 2007.

[11] Kühn F.: Ground Motion Detection Using Persistent Scatter Interferometry - Berlin Case Study. Terrafirma User Workshop Essen March 22, 2011.

[12] Listkowska H.: Objaśnienia do Szczegółowej mapy geologicznej Polski 1:50 000. Arkusz Pakość. Państwowy Instytut Geologiczny, Warszawa 1991.

[13] Lu P., Casagli N., Catani F., Tofani V.: PSI-HSR: a new approach for representing Persistent Scatterer Interferometry (PSI) point targets using the hue and saturation scale. International Journal of Remote Sensing, vol. 31 (8), 2010, pp. 2189-2196.

[14] Lu P., Casagli N., Catani F., Tofani V.: Persistent Scatterers Interferometry Hotspot and Cluster Analysis (PSI-HCA) for detection of extremely slow-moving landslides. International Journal of Remote Sensing, vol. 33 (2), 2012, pp. 466-489.

[15] Perski Z.: Zakres interpretowalności osiadań terenu za pomoca satelitarnej interferometrii radarowej (InSAR). Archiwum Fotogrametrii i Teledetekcji, vol. 9, 1999, pp. 191-201.

[16] Perski Z., Jura D.: ERS SAR Interferometry for the Land Subsidence Detection in Coal Mining Areas. Earth Observation Quartery, vol. 63, 1999, pp. 25-29.

[17] Perski Z., Mróz M.: Zastosowanie metod interferometrii radarowej InSAR do badania naturalnych ruchów powierzchni terenu w Polsce. Projekt Geo-In-SAR. Archiwum Fotogrametrii, Kartografii i Teledetekcji, vol. 17b, 2007, pp. 613-624.

[18] Perski Z., Chybiorz R., Nita J.: Monitoring osiadań terenu pod wptywem eksploatacji gorniczej metoda satelitarnej interferometrii radarowej. Archiwum Fotogrametrii, Kartografii i Teledetekcji, vol. 11, 2001, pp. 35-40.

[19] Perski Z., Ketelaar G., Mróz M.: Interpretacja danych Envisat/ASAR o przemiennej polaryzacji na obszarach zurbanizowanych w kontekście charakterystyki stabilnych rozpraszaczy (persistent scatterers). Archiwum Fotogrametrii, Kartografii i Teledetekcji, vol. 16, 2007, pp. 467-482.

[20] Piątkowska A.: Cechsztyńsko-mezozoiczny kompleks strukturalny Kujaw w świetle cyfrowej analizy danych teledetekcyjnych. Instrukcje i Metody Badań Geologicznych 57, PIG, Warszawa 2003.

[21] Piątkowska A.: Remote Sensing methods for morphotectonic analysis of salt structures. Schriftenereihe der Deutschen Gesellschaft für Geowissenchaften, Heft 53, Geo-Pomerania Szczecin. Geology cross-bordering the Western and Eastern European Platform Joint Meeting DGG-PTG, 2007. 
[22] Piątkowska A., Graniczny M.: Możliwości wykorzystania metod teledetekcyjnych dla identyfikacji mobilności mas solnych i zwiazanych z nimi przemieszczeń powierzchni terenu. [in:] Pilecka E. (red.), Materiały Sympozjum Warsztaty Górnicze z cyklu "Zagrożenia naturalne w górnictwie, Kraków - Tomaszowice, 12-14 czerwca 2006, Wydawnictwo IGSMiE PAN, Kraków 2006.

[23] Piątkowska A., Graniczny M., Surała M., Perski Z.: Application of SAR interferometric methods to identify the mobility of the area above salt diapir in Inowroctaw City, Kujawy region (Poland) Abstract. FRINGE 2011 Workshop 19-23 September 2011, ESA-ESRIN, Frascati (Rome).

[24] Piątkowska A., Surała M., Perski Z., Graniczny M.: Application of SAR interferometric methods to identify the mobility of the area above salt diapir in Inowrocław and the regional salt structures in central Poland. Geology, Geophysics and Environment, vol. 38, no. 2, 2012, pp. 209-220.

[25] Popiołek E., Hermanowski R., Krawczyk A., Perski Z.: Application of Satellite Radar Interferometry to the examination of the areas of mining exploitation. Surface Mining Braunkohle \& Other Minerals, vol 54, no. 1, 2002, pp. 74-82.

[26] Refice A., Bovenga F., Pasquariello G., Denora D., Fidelibus, M. D., Spilotro G.: Bulging of the salt dome of Lesina Marina (Gargano, Southern Italy) revealed by DInSAR techniques. Geophysical Research Abstracts, vol. 13, EGU2011-7954, EGU General Assembly 2011.

[27] Seni S.J., Jackson M.P.A.: Evolution of salt structures, East Texas diapir province. Part 1: Sedimentary record of halokinesis. American Association of Petroleum Geologists Bulletin, vol. 67, no. 8, 1983, pp. 1219-1244.

[28] Szczerbowski Z.: The evaluation of salt dome vertical movements in Inowroctaw detected by classical precise levelling and GPS surveying techniques. Acta Geodynamica et Geomaterialia, vol. 4, no. 4 (148), 2007, pp. 1-10.

[29] Szczerbowski Z.: Toward the reliability of geodetic surveys in study of geodynamics - a problem of influence of seasonal variations. Acta Geodynamica et Geomaterialia, vol. 6, no. 3 (155), 2009, pp. 253-263.

[30] Szczerbowski Z.: The use of land information system in geomorphostructural analysis on the example of Inowroctaw. Acta Geodynamica et Geomaterialia, vol. 7, no. 2 (158), 2010, pp. 153-166.

[31] Szczerbowski Z.: Wpływ uwarunkowań geologicznych i górniczych na lokalne zmiany kierunku linii pionu. Wydawnictwa AGH, Kraków 2010 [with English abstract].

[32] Wrotek K.: Objaśnienia do Szczegółowej mapy geologicznej Polski 1:50 000. Arkusz Złotniki Kujawskie. Państwowy Instytut Geologiczny, Warszawa 1993. 